\title{
PeningKatan Kemampuan Pemecahan dan Hasil Belajar MATEMATIKA MELALUi Problem BASED-LEARNiNG
}

\author{
Enhancing Problem Solving Skill and Learning Result in Mathematics \\ THROUGH PROBLEM BASED-LEARNING
}

\author{
Julita \\ SMAN 10 Kota Bogor \\ Jl. Pinang Raya Sektor VI Komp. Yasmin , Kota Bogor, Jawa Barat, Indonesia \\ Lulita33@yahoo.co.id
}

\begin{abstract}
Abstrak
Penelitian ini bertujuan untuk mengkaji kualitas pengaruh pembelajaran menggunakan metode problem based-learning terhadap peningkatan kemampuan pemecahan masalah dan hasil belajar matematika peserta didik tentang sistem persamaan linear tiga variabel. Penelitian ini menggunakan metode penelitian tindakan kelas (classroom action research) yang difokuskan pada proses pembelajaran dan untuk melakukan perbaikan berdasarkan data kuantitatif dan kualitatif. Objek penelitian adalah peserta didik kelas X MIPA-1 SMAN 10 Kota Bogor. Data kuantitatif diperoleh melalui tes tertulis, sedangkan data kualitatif diperoleh melalui observasi keaktivan peserta didik dan aktifitas guru saat proses pembelajaran. Hasil penelitian menunjukkan bahwa terdapat peningkatan ketuntasan hasil belajar peserta didik yang mencapai 94\% dan terdapat peningkatan keaktivan peserta didik dan guru dalam proses problem basedlearning.

Kata Kunci: problem based-learning, pemecahan masalah, hasil belajar, matematika.
\end{abstract}

\begin{abstract}
The aim of this research is to indentify the quality of learning influence using problem basedlearning method against the increased of students problem solving ability and learning outcome in mathematics concerning linear equation systems of three variable. The methods that is used is classroom action research that focused on learning process to upgrade it based on quantitative and qualitative data. The object of this research are students in classroom X MIPA-1 SMAN 10 Kota Bogor. Quantitative data obtained from written test, meanwhile, qualitative data from observation of students and teachers activeness when learning process conducted in the classroom. The result shows that there are increasing in students learning completeness that reach 94\% and in students and teachers activeness in problem based-learning process.

Keyword: problem based-learning, problem solving, learning result, mathematics.
\end{abstract}




\section{Pendahuluan}

Pendidikan memiliki peran penting dalam menciptakan sumber daya manusia (SDM) yang berkualitas. Peningkatan kualitas SDM dapat dilakukan dengan menyelenggarakan pendidikan yang bermutu, yaitu pendidikan yang sesuai dengan harapan peserta didik, masyarakat dan pemerintah (Jamaris, 2013). Kualitas pembelajaran dapat dilihat dari segi proses dan hasil (Amir \& Risnawati, 2016). Pembelajaran berkualitas dari segi proses apabila seluruh atau sebagian besar peserta didik terlibat aktif secara fisik, mental, maupun sosial dalam kegiatan pembelajaran. Selanjutnya, pembelajaran berkualitas dari segi hasil apabila terjadi perubahan tingkah laku ke arah positif dan tercapainya tujuan pembelajaran yang sudah ditetapkan.

Matematika merupakan salah satu mata pelajaran yang diajarkan pada setiap jenjang pendidikan. Matematika dianggap dapat membentuk peserta didik yang mampu menghadapi perkembangan dunia, terutama perkembangan ilmu pengetahuan, teknologi dan komunikasi. Penguasaan matematika dianggap penting untuk memenuhi kebutuhan pengembangan ilmu matematika itu sendiri, ilmu lain, maupun untuk kehidupan sehari-hari.

Berdasarkan Permendikbud nomor 21 tahun 2016, sebagai upaya mewujudkan tujuan pendidikan nasional telah ditetapkan standar kompetensi Iulusan yaitu kriteria tentang kualifikasi kemampuan lulusan yang mencakup sikap, pengetahuan, dan keterampilan. Selanjutnya, untuk mencapai kompetensi Iulusan tersebut perlu ditetapkan Standar Isi yaitu kriteria tentang ruang lingkup materi dan tingkat kompetensi peserta didik pada jenjang dan jenis pendidikan tertentu. Selain itu, untuk memenuhi kebutuhan masa depan pemerintah telah menetapkan standar kompetensi lulusan yang berbasis pada kompetensi abad XXI, yaitu kompetensi berpikir kritis, kreatif dan mampu memecahkan masalah.

Pemecahan masalah merupakan bagian tak terpisahkan dari proses pembelajaran matematika yang mengharuskan peserta didik untuk berpikir (Julita, 2017). Proses berpikir dapat dikembangkan melalui masalah matematika yang menantang dan tidak rutin (Sabandar, 2008). Masalah tidak rutin, proses penyelesaiannya membutuhkan pemikiran lebih lanjut karena prosedur penyelesaiannya tidak sama dengan yang diajarkan di kelas. Proses pemecahan masalah memberi kesempatan kepada peserta didik terlibat aktif dalam mempelajari, mencari, menemukan sendiri informasi untuk diolah menjadi konsep, prinsip, teori, atau kesimpulan (Sumiati \& Asra, 2009).

Kemampuan pemecahan masalah matematik merupakan kemampuan memproses informasi terkait konsep matematika untuk membuat keputusan. Kemampuan peserta didik dalam memproses informasi untuk memecahkan masalah matematika berbeda-beda tergantung dari latar belakang kemampuan siswa dalam menggunakan 
penalaran, yaitu kemampuan melihat hubungan sebab akibat untuk menarik kesimpulan.

Julita (2017) berpendapat bahwa kemampuan pemecahan masalah merupakan kemampuan memproses informasi dan menyusun berbagai alternatif pemecahan masalah untuk mencapai tujuan yang diinginkan. Selain itu, pemecahan masalah merupakan penyelesaian persoalan yang tidak rutin dan merupakan proses berpikir tingkat tinggi, serta sangat dibutuhkan dalam pembelajaran matematika.

Namun kenyataannya, masih banyak peserta didik kelas X MIPA-1 SMAN 10 Kota Bogor belum mampu mengembangkan kemampuan pemecahan masalah matematik yang dimilikinya. Hal ini disebabkan peserta didik belum paham masalah yang berdampak terhadap penyelesaian masalah menjadi kurang tepat. Kesulitan peserta didik menerapkan langkah-langkah pemecahan masalah matematik berdasarkan Polya, yaitu pada langkah memahami masalah. Pada saat kegiatan pembelajaran berlangsung peserta didik mampu memahami masalah, tapi pada saat tes hanya sebagian kecil peserta didik mampu menyelesaikan masalah dengan benar. Kesulitan lain yang dialami peserta didik ketika merencanakan penyelesaian masalah, hanya sebagian kecil peserta didik mampu menentukan teknik yang akan digunakan untuk menyelesaikan masalah.

Ketidakmampuan peserta didik dalam pemecahan masalah akan berdampak terhadap penyelesaian masalah dalam kehidupannya. Peserta didik kurang kompeten dalam menyelesaikan masalah yang dihadapi, meskipun masalah tersebut tergolong ringan. Lebih jauh lagi, peserta didik menjadi putus asa dan mengambil jalan pintas terhadap penyelesaian permasalahan yang dihadapi. Hal seperti ini diharapkan jangan sampai terjadi. Oleh sebab ini, guru perlu berupaya dalam melatih keterampilan peserta didik dalam pemecahan masalah.

PBL memfokuskan peserta didik untuk bersikap aktif, tidak hanya pasif memperhatikan pengajaran dari guru. Peserta didik dapat mengemukakan pemikirannya, saling bertukar pendapat, saling bekerja sama jika ada teman dalam kelompok yang mengalami kesulitan. Penerapan PBL ini diharapkan dapat mengatasi rendahnya kemampuan pemecahan masalah matematis pada materi sistem persamaan linear tiga variabel (SPLTV) di kelas X MIPA-1 SMAN 10 Kota Bogor. Melalui PBL diharapkan dapat mengatasi kesulitan belajar peserta didik, karena dapat mempengaruhi pencapaian ketuntasan dalam belajar.

Kriteria ketuntasan minimal (KKM) adalah kriteria paling rendah untuk menyatakan peserta didik mencapai ketuntasan. Satuan pendidikan harus menetapkan KKM semua mata pelajaran sebagai dasar dalam menilai pencapaian kompetensi peserta didik. Peserta didik dikatakan tuntas atau berhasil menguasai suatu kompetensi apabila telah mencapai nilai KKM. Berdasarkan hasil analisis dan 
kesepakatan guru mata pelajaran, maka KKM kelas X SMAN 10 Bogor tahun pelajaran 2017/2018 sebesar 70.

Hasil tes matematika pada pra penelitian materi sistem persamaan linear dua variabel (SPLDV) di kelas X MIPA-1 SMAN 10 Bogor hanya sekitar 24\% atau 8 orang peserta didik yang mencapai nilai KKM. Berarti sekitar $76 \%$ atau 26 orang peserta didik belum mencapai KKM. Ratarata perolehan hasil tes peserta didik tentang SPLDV hanya sebesar 60,44. Ini menunjukkan hasil belajar matematika peserta didik pada materi sistem persamaan linear tiga variabel (SPLTV) di kelas X MIPA-1 SMAN 10 Kota Bogor masih rendah.

Beranjak dari kondisi tersebut, upaya guru dalam meningkatkan kemampuan pemecahan masalah dan hasil belajar matematika peserta didik dengan melaksanakan kegiatan pembelajaran menggunakan problem based-learning (PBL). Proses pembelajaran melalui PBL diperkirakan dapat menjadi suatu alternatif metode pembelajaran yang efektif meningkatkan hasil belajar siswa yang di dalamnya tersirat kemampuan pemecahan masalah matematik.

Berdasarkan pemikiran tersebut, penulis tertarik untuk melakukan suatu penelitian tindakan kelas sebagai upaya meningkatkan kemampuan pemecahan masalah dan hasil belajar matematika peserta didik kelas X MIPA-1 SMA Negeri 10 Kota Bogor materi sistem persamaan linear tiga variabel (SPLTV) melalui problem based-learning (PBL).

\section{Metode}

Penelitian menggunakan metode penelitian tindakan kelas (Classroom Action Research) yang difokuskan pada proses pembelajaran dan bertujuan untuk melakukan perbaikan dan meningkatkan layanan profesionalisme guru. Tujuan penelitian dapat dicapai dengan melakukan refleksi dalam mendiagnosa keadaan dan mengembangkan secara sistematis tindakan alternatif sebagai upaya pemecahan permasalahan pembelajaran yang sedang dihadapi.

Penelitian ini dilaksanakan di Sekolah Menengah Atas Negeri (SMAN) 10 Kota Bogor dengan alamat jalan Pinang Raya Sektor VI Kompleks Yasmin. Subyek dalam penelitian ini adalah peserta didik kelas $X$ MIPA-1 sebanyak 34 orang yang terdiri dari 16 laki-laki dan 18 perempuan dengan kemampuan matematika yang berbeda, tetapi hampir merata. Materi pembelajaran matematika pada penelitian ini adalah sistem persamaan linear tiga variabel (SPLTV).

Instrumen yang digunakan untuk mengumpulkan data pada penelitian ini adalah tes uji kompetensi untuk memperoleh data hasil belajar peserta didik yang dilaksanakan setelah pembelajaran berlangsung. Selain itu, instrumen yang digunakan adalah lembar observasi untuk memperoleh gambaran aktivitas peserta didik dan tindakan yang dilakukan guru saat proses pembelajaran berlangsung. 
Penelitian tindakan kelas ini dilaksanakan dalam empat tahapan sesuai dengan model John Elliot (Muslihuddin, 2011:72) yang dimulai dari perencanaan, pelaksanaan, pengamatan, dan refleksi. Penelitian Tindakan Kelas dimulai dengan menyusun perencanaan yang dilaksanakan pada tahap pelaksanaan dan pengamatan. Tahap pelaksanaan dan pengamatan dilaksanakan dalam waktu yang bersamaan, yaitu pengamatan dilakukan saat proses pembelajaran berlangsung di kelas. Setelah pelaksanaan dan pengamatan selesai dilaksanakan, dilanjutkan dengan melakukan refleksi, yaitu kegiatan untuk mengkaji dan mengevaluasi pelaksanaan proses pembelajaran yang sudah dilakukan.

Data yang diperoleh pada setiap siklus dianalisis berdasarkan kategori data. Data kuantitatif diperoleh dari hasil tes kompetensi materi pembelajaran SPLTV, sedangkan data kualitatif diperoleh dari hasil observasi yang dilakukan oleh observer. Bertindak sebagai observer pada penelitian ini adalah teman sejawat sesama guru matematika di SMAN 10 Kota Bogor.

Indikator keberhasilan tindakan yang sudah dilakukan terhadap peningkatan hasil belajar peserta didik tentang SPLTV pada mata pelajaran matematika di kelas $X$ MIPA-1 SMAN 10 Bogor seperti yang ditampilkan pada Tabel 1 berikut ini.
Tabel 1.

Indikator Keberhasilan Tindakan

\begin{tabular}{llc|}
\hline \multicolumn{1}{c}{$\begin{array}{c}\text { Ukuran } \\
\text { keberhasilan }\end{array}$} & \multicolumn{1}{c}{ Target } & $\begin{array}{c}\text { Teknik } \\
\text { Pengumpulan } \\
\text { Data }\end{array}$ \\
\hline $\begin{array}{l}\text { Ketuntasan } \\
\text { perorangan }\end{array}$ & $\begin{array}{l}\text { ada 2 siswa di } \\
\text { bawah KKM }\end{array}$ & Tes \\
\hline $\begin{array}{l}\text { Ketuntasan } \\
\text { klasikal }\end{array}$ & $\begin{array}{l}\text { 85\% siswa } \\
\text { mencapai KKM }\end{array}$ & Tes \\
\hline $\begin{array}{l}\text { Keaktivan } \\
\text { peserta didik }\end{array}$ & $\begin{array}{l}\text { 75\% } \\
\text { keaktivannya } \\
\text { baik }\end{array}$ & Observasi \\
\hline $\begin{array}{l}\text { Rata-Rata hasil } \\
\text { belajar klasikal }\end{array}$ & minimal 70 & Tes \\
\hline Aktivitas guru & $85 \%$ PBL baik & Observasi \\
\hline
\end{tabular}

\section{Hasil dan Pembahasan}

Analisis hasil penelitian tindakan kelas dilakukan berdasarkan data kuantitatif dan kualitatif yang diperoleh. Data kuantitatif diperoleh dari hasil tes, sedangkan data kualitatif diperoleh dari hasil observasi saat proses pembelajaran.

\section{A. Deskripsi Kondisi Awal}

Sebelum melakukan tindakan dalam penelitian, peneliti melakukan observasi awal di kelas. Hasil observasi menunjukkan bahwa ketika guru mengajar materi prasyarat untuk mempelajari materi sistem persamaan linear tiga variabel (SPLTV), yaitu sistem persamaan linear dua variabel (SPLDV) dengan cara konvensional atau ceramah, diperoleh nilai rata-rata hasil belajar 60,44 sedangkan KKM yang ditentukan 70. Peserta didik yang mendapatkan nilai lebih dari atau sama dengan KKM berjumlah 8 orang (24\%), sedangkan peserta didik yang mendapat nilai di bawah KKM 26 orang (76\%).

Hasil pengamatan awal proses pembelajaran di kelas, menunjukkan 
bahwa pembelajaran yang dilakukan guru menggunakan metode ekspositori, namun cenderung masih berpegang pada cara mengajar konvesional. Guru menerangkan materi, peserta didik mencatat, dan guru mengajukan pertanyaan pada peserta didik. Selanjutnya guru memberikan soal latihan untuk dikerjakan. Jika ada peserta didik yang sudah selesai, maka peserta didik tersebut mengerjakan soal di papan tulis dengan hanya menuliskan jawaban tanpa harus memberi penjelasan tentang apa yang dituliskannya.

Proses pembelajaran yang dilakukan guru tidak memberikan kesempatan pada peserta didik untuk menelaah dan mencermati permasalahan, sehingga sulit baginya untuk mengidentifikasi permasalahan. Peserta didik tidak memahami permasalahan yang dihadapi. Hal ini berdampak pada kemampuan peserta didik dalam pemecahan masalah. Selain itu, komunikasi yang terjadi dalam proses pembelajaran hanya satu arah yaitu antara guru dengan peserta didik. Tidak terjadi komunikasi di antara peserta didik.

\section{B. Analisis Data Hasil Penelitian}

Untuk mengetahui keberhasilan penelitian dilakukan serangkaian analisis, diantaranya dilakukan analisis hasil dan ketuntasan belajar, serta keaktifan peserta didik dan aktifitas guru saat proses pembelajaran untuk setiap siklus tindakan. Data hasil dan ketuntasan belajar yang dianalisis diperoleh dari hasil tes diakhir pra siklus, siklus I, dan siklus II.
Data rekapitulasi tingkat penguasaan materi pembelajaran peserta didik diakhir pra-siklus, siklus I, dan siklus II ditunjukkan pada grafik (gambar 1) berikut ini.

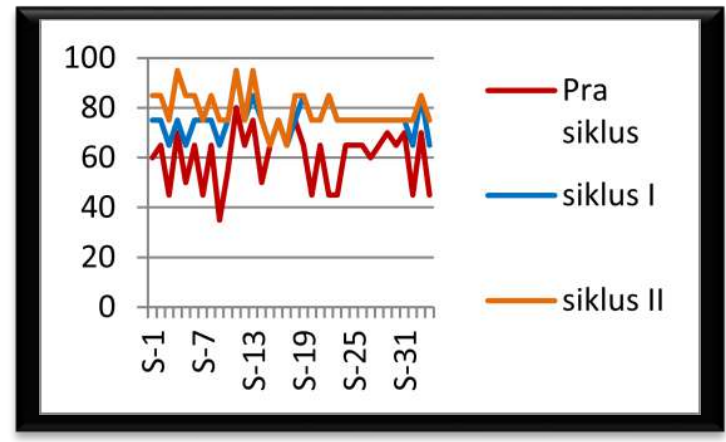

Gambar 1. Rekapitulasi Tingkat Penguasaan Materi Pembelajaran.

Dari gambar 1 diketahui bahwa pada dasarnya terdapat peningkatan penguasaan materi pembelajaran setiap peserta didik dari pra-siklus, siklus I, dan siklus II. Meskipun pada siklus II penguasaan materi pembelajaran beberapa peserta didik tidak meningkat, tapi sama dengan penguasaan materi pembelajaran pada siklus I. Penguasaan materi pembelajaran mengalami peningkatan yang tinggi dari pra-siklus ke siklus II.

Data rekapitulasi hasil belajar peserta didik dilihat dari nilai terendah dan tertinggi, nilai rata-rata, serta persentase ketuntasan belajar pada pra-siklus, siklus I, dan siklus II ditunjukkan oleh diagram batang (gambar 2) berikut ini. 


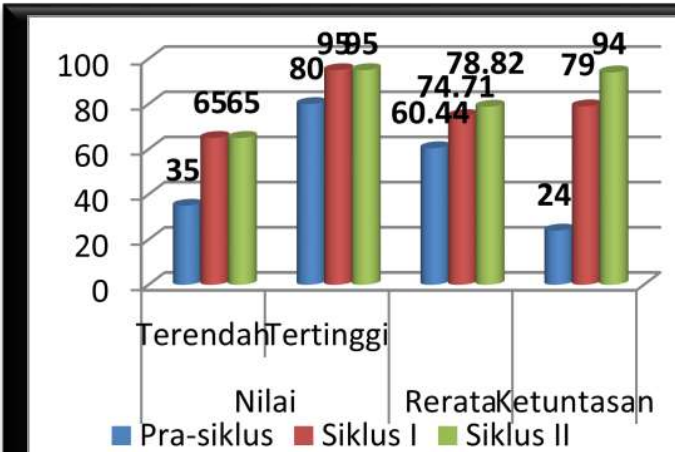

Gambar 2. Rekapitulasi Hasil Belajar Peserta Didik.

Dari gambar 2 dapat dilihat perolehan nilai terendah dan tertinggi pada pra-siklus adalah 35 dan 80. Perolehan nilai terendah dan tertinggi di siklus I mengalami peningkatan yaitu 65 dan 95, sedangkan pada siklus II tidak mengalami peningkatan yaitu tetap 65 dan 95.

Selanjutnya, rerata hasil belajar peserta didik juga mengalami peningkatan. Pada pra-siklus 60,44 meningkat menjadi 74,71 pada siklus I dan mengalami peningkatan lagi pada siklus II menjadi 78,82.

Peningkatan hasil belajar peserta didik juga ditunjukkan oleh persentase ketuntasan belajar. Pada pra-siklus peserta didik yang tuntas sebesar 24\%, mengalami peningkatan pada siklus I sebesar 79\%. Selanjutnya pada siklus II meningkat lagi menjadi 94\%.

Data pada gambar 3.1 dan 3.2 menunjukkan bahwa terdapat peningkatan hasil dan ketuntasan belajar peserta didik. Persentase ketuntasan belajar sudah melampaui persentase ketuntasan yang direkomendasikan pemerintah, yaitu $85 \%$ setelah diberi perlakuan pembelajaran menggunakan metode problem based-learning (PBL). Hal ini berarti pembelajaran melalui metode PBL efektif dalam meningkatkan hasil belajar peserta didik.

Hasil observasi keaktifan peserta didik selama proses pembelajaran pada prasiklus, siklus I, dan siklus II ditunjukkan pada gambar 3 berikut ini.

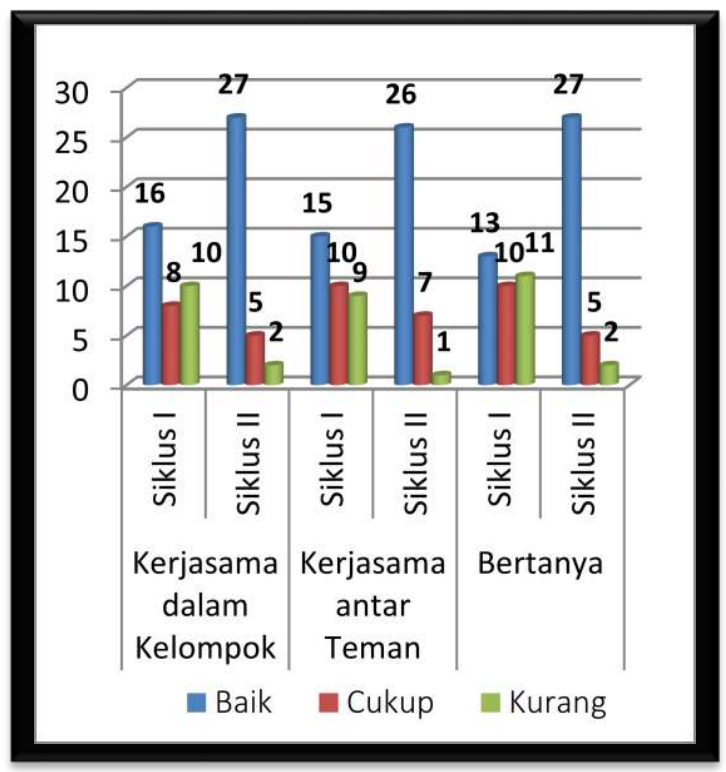

Gambar 3. Hasil Observasi Keaktifan Peserta Didik.

Data pada gambar 3 menunjukkan peningkatan keaktifan peserta didik dalam bekerjasama di kelompoknya. Pada siklus I terdapat 15 orang (44\%) dengan kategori baik, 10 orang (29\%) kategori cukup dan 9 orang $(27 \%)$ yang masih termasuk kategori kurang. Pada siklus II terjadi peningkatan 26 orang (76\%) dengan kategori baik, 7 orang (21\%) kategori cukup, dan hanya 1 orang (3\%) yang masih termasuk kategori kurang antusias bekerjasama di kelompoknya.

Data pada gambar 3.3 juga menunjukkan peningkatan keaktifan peserta didik bekerjasama antar teman di 
kelasnya. Pada siklus I terdapat 13 orang (38\%) dengan kategori baik, 10 orang (30\%) kategori cukup, dan 11 orang (32\%) yang masih termasuk kategori kurang. Pada siklus II terjadi peningkatan 27 orang (79\%) dengan kategori baik, 5 orang (15\%) kategori cukup, dan hanya 2 orang (6\%) yang masih termasuk kategori kurang antusias bekerjasama antar teman di kelasnya.

Selain peningkatan keaktifan peserta didik dalam bekerjasama di kelompoknya dan bekerjasama antar teman di kelasnya, data 3.3 juga menunjukkan peningkatan keaktifan peserta didik dalam bertanya. Pada siklus I terdapat 16 orang yang tingkat keaktifannya termasuk kategori baik, 10 orang cukup aktif, dan 12 orang kurang aktif pada saat pembelajaran. Setelah guru melakukan perbaikan berdasarkan hasil refleksi pada siklus I, maka pada siklus II terdapat peningkatan yaitu 30 orang yang aktif, 6 orang cukup aktif, dan 2 orang tidak aktif pada saat pembelajaran.

Secara keseluruhan data pada gambar 3.3 menunjukkan terdapat peningkatan aktifitas peserta didik selama proses pembelajaran menggunakan metode PBL. Peningkatan aktifitas umumnya dengan menunjukkan sikap positif, yaitu aktifitas diskusi, memecahkan masalah, bertanya dan menjawab pertanyaan. Hal ini berarti bahwa pembelajaran menggunakan metode problem based-learning (PBL) berhasil melibatkan peserta didik secara aktif dalam pembelajaran. Selain itu, PBL juga mampu menciptakan suasana belajar yang efektif dengan sedikitnya perilaku peserta didik yang tidak relevan seperti bercanda dan ngobrol selama kegiatan pembelajaran, sehingga secara umum pembelajaran ini berlangsung sangat efektif dalam meningkatkan kemampuan pemecahan masalah matematik peserta didik.

Hasil observasi aktifitas guru selama proses pembelajaran pada pra-siklus, siklus I, dan siklus II ditunjukkan pada gambar 4 berikut ini.

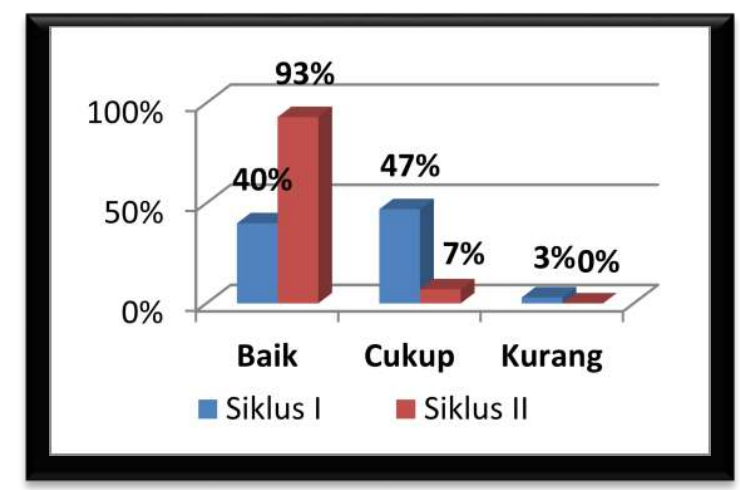

Gambar 4. Hasil observasi Aktifitas Guru.

Data pada gambar 4 menunjukkan bahwa aktifitas guru pada siklus I secara umum sudah cukup baik, namun ada beberapa komponen penilaian dari observer yang masih kurang yaitu kemampuan pengelolaan waktu yang kurang optimal dan kurang memotivasi peserta didik sehingga semangat peserta didik pada siklus I masih kurang. Kekurangan pada siklus I ini kemudian diperbaiki pada siklus II dengan mengatur waktu lebih efisien dan lebih memotivasi semangat belajar peserta didik dengan menciptakan suasana belajar yang menyenangkan. Aktivitas guru pada siklus 
II 93\% sudah baik, berarti aktivitas guru secara umum sudah baik.

Data pada gambar 3.4 secara umum menunjukkan bahwa aktivitas guru dalam pembelajaran menggunakan metode PBL sudah baik. Guru dapat mengaplikasikan kegiatan pembelajaran sesuai dengan metode PBL. Hal ini berarti, proses pembelajaran menggunakan metode $\mathrm{PBL}$ akan efektif bila guru kreatif membuat masalah kontekstual terkait materi pembelajaran dan guru mampu memotivasi peserta didik untuk aktif dalam kegiatan pembelajaran. Guru harus mampu menciptakan suasana belajar yang menyenangkan.

\section{Pembahasan Hasil Penelitian}

Pembelajaran menggunakan metode problem based-learning (PBL) sebagai upaya untuk meningkatkan kemampuan pemecahan masalah dan hasil belajar matematik peserta didik, umumnya sudah sesuai dengan rencana dan tujuan pembelajaran yang diinginkan. Penguasaan materi pembelajaran dan nilai rata-rata kelas dalam pembelajaran dengan menggunakan metode PBL ini pada umumnya terdapat peningkatan untuk setiap tindakan.

Peningkatan ketuntasan belajar secara klasikal yang menjadi acuan guru dalam melakukan evaluasi pembelajaran cukup tinggi. Pada evaluasi pra-siklus sampai evaluasi akhir siklus II sudah mencapai ketuntasan yang direkomendasikan Depdiknas, yaitu minimal 85\%. Hal ini menunjukkan bahwa kemampuan pemecahan masalah matematik mengalami peningkatan pada pembelajaran dengan metode PBL. Peningkatan kemampuan pemecahan masalah terjadi karena dalam proses pembelajaran metode PBL peserta didik berlatih memperbaiki serta mengembangkan strategi yang mereka gunakan untuk memecahkan masalah berbeda, non rutin, terbuka, dan situasi yang berbeda (Amir dan Risnawati, 2016).

Dalam proses pembelajaran matematika, guru dan peserta didik berperan penting terhadap tercapainya tujuan pembelajaran. Keaktifan peserta didik dalam proses pembelajaran metode PBL secara keseluruhan mengalami peningkatan. Keaktifan peserta didik bekerjasama dalam kelompok dan antar teman di kelas, serta keaktifan dalam bertanya secara umum memiliki kategori baik. Hal ini menunjukkan bahwa pembelajaran dengan metode PBL berjalan secara efektif, karena dapat meningkatkan aktifitas pembelajaran peserta didik. Menurut Sanjaya (2016), salah satu kelebihan pembelajaran dengan metode PBL dapat meningkatkan aktivitas belajar peserta didik.

Aktivitas guru dalam proses pembelajaran dengan metode PBL 93\% baik atau sudah sesuai dengan langkahlangkah kegiatan yang direncanakan, sehingga pembelajaran dapat berjalan kondusif dan efektif. Pembelajaran efektif adalah pembelajaran yang mampu melibatkan seluruh peserta didik secara aktif (Amir dan Risnawati, 2016). 
Pembelajaran yang dilakukan guru dapat dikategorikan berhasil dan berkualitas karena seluruh atau sebagian besar peserta didik terlibat secara aktif, baik fisik, mental, maupun sosial dalam proses pembelajaran (Amir dan Risnawati, 2016).

Secara umum, pembelajaran menggunakan metode problem basedlearning (PBL) pada materi sistem persamaan linear tiga variabel (SPLTV) sangat efektif dalam meningkatkan kemampuan pemecahan masalah dan hasil belajar peserta didik melalui aktivitas mengidentifikasi masalah, berdiskusi, mempresentasikan, serta menganalisis dan mengevaluasi proses pemecahan masalah. Akan tetapi, dari hasil pengamatan dan analisa penggunaan metode PBL terdapat kelemahan dan kelebihan. Kelemahan metode PBL antara lain:

1. Menyusun permasalahan kontekstual yang sesuai dengan materi pembelajaran dan tingkat berpikir peserta didik. Apabila permasalahan terlalu sulit dipahami oleh peserta didik, maka minat belajarnya akan berkurang. Peserta didik enggan mencoba menyelesaikan masalah.

2. Waktu yang dibutuhkan peserta didik memecahkan masalah cukup lama, sehingga sulit menyesuaikan dengan alokasi waktu yang sudah direncanakan. Kelebihan pembelajaran dengan metode problem based-learning (PBL) antara lain:

1. Aktivitas belajar peserta didik lebih meningkat, karena mereka disibukkan dengan berbagai aktivitas berusaha mengidentifikasi masalah, berdiskusi mencari solusi pemecahan masalah, dan mempresentasikan hasil diskusi, serta melakukan analisis dan evaluasi terhadap pemecahan masalah.

2. Peserta didik dapat lebih meningkatkan kemampuan pemecahan masalahnya dengan berbagai permasalahan yang dihadapi.

3. Peserta didik menjadi lebih tertantang kemampuannya untuk berusaha menyelesaikan permasalahan.

4. Berusaha memecahkan masalah akan lebih mengembangkan kemampuan berpikir kritis peserta didik.

Pembelajaran dengan metode PBL memberi kepercayaan pada peserta didik untuk membangun pengetahuan baru dari pengetahuan (informasi) yang sudah ada dalam dirinya. Guru sebagai fasilitator hanya mendampingi peserta didik dalam proses pemecahan masalah. Peserta didik diharapkan memiliki kepuasan dengan berhasil memecahkan masalah, sehingga pengetahuan yang diperoleh lebih lama tersimpan dalam memorinya.

\section{Penutup}

Berdasarkan hasil analisis data dari penelitian tindakan kelas yang sudah dilakukan, maka diperoleh kesimpulan sebagai berikut: 1) Terdapat peningkatan kemampuan pemecahan masalah dan hasil belajar peserta didik tentang sistem persamaan linear tiga variabel (SPLTV) melalui problem based-learning (PBL) di kelas X MIPA-1 SMA Negeri 10 Bogor; 2) 
Keaktifan peserta didik dalam proses pembelajaran melalui problem basedlearning (PBL) lebih baik dibandingkan sebelum menggunakan PBL; dan 3) Peningkatan kemampuan pemecahan masalah dan hasil belajar peserta didik tentang sistem persamaan linear tiga variabel (SPLTV) melalui metode problem based-learning (PBL) di kelas X MIPA-1 SMA Negeri 10 Bogor sudah mencapai indikator keberhasilan tindakan yang ditargetkan.

Berdasarkan hasil penelitian, berikut ini saran-saran yang diharapkan dapat bermanfaat untuk perbaikan, yaitu: 1) Bagi Guru, melakukan problem based-learning (PBL) dalam pembelajaran matematika pada materi pembelajaran lainnya. Untuk mengatasi kelemahan PBL terdapat beberapa hal yang perlu dipersiapkan, antara lain: perlu perencanaan dalam menyusun permasalahan kontekstual sesuai materi pembelajaran, sehingga waktu yang tersedia dapat dimanfaatkan secara efektif; untuk menghindari diskusi kelompok yang terlalu lama, peserta didik perlu difokuskan pada pokok permasalahan; dan 2) Bagi Peneliti Lain, perlu dilakukan penelitian yang sejenis dengan subjek yang lebih luas dengan materi pembelajaran yang berbeda. Selain itu, untuk menyempurnakan penelitian perlu dibantu oleh pihak lain untuk merekam proses pembelajaran yang selalu tertuju pada fokus pengamatan.

\section{Daftar Pustaka}

Amir, Z. \& Risnawati. (2016). Psikologi Pembelajaran Matematika. Yogyakarta: Aswaja Pressindo Arends, R. I. (1997). Classroom Instruction and Management. New York: The McLGraw-Hill Companies, Inc.

Hamruni. (2012). Strategi Pembelajaran. Yogyakarta: Insan Madani.

Jamaris, M. (2013). Orientasi Baru dalam Psikologi Pendidikan. Bogor: Ghalia Indonesia

Julita. (2017). The enhancement of mathematical problem solving ability of senior high school students through quantum learning. Journal of Mathematics Education, Infinity. Volume 6, No. 1.

Muslihuddin. (2011). Kiat Sukses Melakukan Penelitian Tindakan Kelas \& Sekolah. Bandung: Rizqi Press.

Permendikbud. (2016). Standar Isi Pendidikan Dasar dan Menengah. Jakarta: BSNP.

Sabandar, J. (2008). Thinking Classroom dalam Pembelajaran Matematika di Sekolah. Simposium Internasional. Bandung: Universitas Pendidikan Indonesia.

Sanjaya, W. (2016). Strategi Pembelajaran Berorientasi Standar Proses Pendidikan. Jakarta: Prenadamedia Group.

Sumiati \& Asra. (2009). Metode Pembelajaran. Bandung: CV. Wacana Prima.

Yamin, M. (2013). Strategi dan Metode dalam Model Pembelajaran. Jakarta: Referensi (GP Press Group). 


\section{Riwayat Hidup Penulis}

Julita, S.Pd. M.Pd.

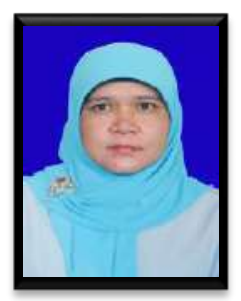

Lahir di Bangka, 24 Juli 1970.

Staf pengajar di Universitas

Pakuan Bogor dan SMAN 10

Kota Bogor. Studi S1

Pendidikan Matematika di

Universitas Negeri Jakarta

dan lulus tahun 2001. S2

Pendidikan Matematika,

universitas terbuka (UT) Jakarta dan lulus tahun 2014. Sekarang masih kuliah di S3 Pendidikan Matematika Universitas Pendidikan Indonesia. 